\title{
Tropical Street Trees and Climate Uncertainty in Southeast Asia
}

\author{
Roger Kjelgren ${ }^{1}$ \\ Department of Plants, Soils and Climate, Utah State University, 4820 Old Main Hill, Logan, UT 84322-4820 \\ Yongyut Trisurat \\ Department of Forest Biology, Kasetsart University, 50 Pahonyothin Road, Bangkok 10900, Thailand \\ Ladawan Puangchit \\ Department of Silviculture, Kasetsart University, 50 Pahonyothin Road, Bangkok 10900, Thailand \\ Nestor Baguinon \\ Department of Forest Biological Sciences, College of Forestry and Natural Resources, University of the \\ Philippines Los Baños, College, Laguna, Philippines \\ Puay Tan Yok \\ Center for Urban Greening and Ecology, National Parks Board, Singapore
}

Additional index words. climate change, water stress, drought physiology, drought deciduous, wet evergreen, monsoonal dry evergreen, urban forestry

\begin{abstract}
Urban trees are a critical quality of life element in rapidly growing cities in tropical climates. Tropical trees are found in a wide variety of habitats governed largely by the presence and duration of monsoonal dry periods. Tropical cities can serve as a proxy for climate change impacts of elevated carbon dioxide $\left(\mathrm{CO}_{2}\right)$, urban heat island, and drought-prone root zones on successful urban trees. Understanding the native habitats of species successful as tropical urban trees can yield insights into the potential climate impact on those habitats. Species from equatorial and montane wet forests where drought stress is not a limiting factor are not used as urban trees in cities with monsoonal dry climates such as Bangkok and Bangalore. Absence of trees from a wet habitat in tropical cities in monsoonal climates is consistent with model and empirical studies suggesting wet evergreen species are vulnerable to projected climates changes such as lower rainfall and increased temperatures. However, monsoonal dry forest species appear to have wider environmental tolerances and are successful urban trees in cities with equatorial wet climates such as Singapore as well as cities with monsoonal climates such as Bangkok and Bangalore. In cities with monsoonal dry climates, deciduous tree species are more common than dry evergreen species. Although dry deciduous species generally have better floral displays, their prevalence may in part be the result of greater tolerance of urban heat islands and drought in cities; this would be consistent with modeled habitat gains at the expense of dry evergreen species in native forest stands under projected higher temperatures from climate change. Ecological models may also point to selection of more heat- and drought-tolerant species for tropical cities under projected climate change.
\end{abstract}

\section{TROPICAL URBAN TREES}

Urban trees are an increasingly important quality of life issue in tropical cities as economic growth swells increasingly affluent urban populations (Nilsson, 2005). The understanding and management of urban trees in tropical cities, particularly the street-side population, is based on a modest body of scientific knowledge while facing an uncertain future climate. We propose that tropical urban tree management and potential climate impacts can be understood in the context of cities as a proxy for climate change; which urban tree species have succeeded in tropical cities can yield insights into potential climate-induced changes in tropical forest types. In turn, which tropical tree species that may adapt best to

Received for publication 10 Sept. 2010. Accepted for publication 16 Nov. 2010.

This paper was part of the colloquium "Water Management and Plant Performance in a Changing Climate" held 4 Aug. 2010 at the ASHS Conference, Palm Desert, CA, and sponsored by the Water Utilization and Plant Performance in a Changing Climate (WUM) Working Group.

${ }^{1}$ To whom reprint requests should be addressed; e-mail roger.kjelgren@usu.edu. climate change offer a selection pool for increasing tropical urban tree diversity.

Urban, freestanding trees growing along streets, in street medians, or on private property are a critical foundation for both a healthy human population and healthy economy (Tzoulas et al., 2007). The UN-World Health Organization recommends at least $9 \mathrm{~m}^{2}$ of urban green space per capita to mitigate several undesirable environmental effects and provide aesthetic benefits (Deloya, 1993). Urban forests are particularly critical to healthy cities in developing countries with some of the world's largest metropolitan areas. Green space and urban trees become increasingly important where the rate of urbanization is greatest in developing countries, mostly smaller cities of $\approx 500,000$ in Asia and Africa (United Nations Dept. Economic and Social Affairs, 2003).

Tropical cities in developing countries have a large diverse pool of adapted species available from tropical forests (Jim and Liu, 2001). Selection of tree species best suited for tropical urban conditions depends on matching above- and below-ground space (Jim, 2001) and urban climate to species from an appropriate tropical forest type. Selecting for urban trees from an appropriate tropical forest type depends on where a tropical city falls along the seasonality gradient of rainfall distribution between aseasonal wet (no dry periods) and a monsoonal climate (alternating dry and wet seasons of varying length). Cities in equatorial wet climates, such as Singapore in Southeast Asia, will logically use trees from equatorial wet evergreen-aseasonal forests. However, cities in wet equatorial climates can possibly use drought-adapted trees from monsoonal climates (Tee and Wee, 2001), similar in strategy to temperate cities using tree species from colder climates. Tropical monsoonal dry forest species are adapted to forest environments subject to several months of low rainfall (Miles et al., 2006). Tropical dry forest species either avoid drought with deciduous leaf habit or tolerate drought with evergreen foliage (Santiago et al., 2004). When grown in a wet evergreen environment, drought deciduous species often retain their leaves most of the year, sometimes shedding foliage briefly during short dry periods (Brodribb and Holbrook, 2005).

It appears, however, that wet evergreen species generally are not used in tropical cities with monsoonal climates and pronounced dry seasons. Street trees in Bangkok were dominated by deciduous species, mostly native to Southeast Asia but also from Africa and South 
America (Thaiutsa et al., 2008), because they typically have more ornamental floral displays. Dry evergreen species were more common as older, large-specimen trees, but most were older and often declining specimens found in protected urban locations (Thaiutsa et al., 2008). Similarly, Nagendra and Gopal (2010) reported that deciduous trees dominated the street-side tree population in Bangalore, and of the evergreen species, only one was ostensibly from a wet evergreen forest.

Understanding the differences in ecological physiology between dry and wet tropical forest species can possibly help explain the relative distribution and abundance of deciduous and evergreen species in tropical cities. Combined with insights into forest change from model projections under increased temperature scenarios and paleoclimate reconstructions, tropical cities can potentially select appropriate deciduous and evergreen tropical species better adapted to future hotter and drier urban conditions beyond model projections. Reciprocally, urban microclimates can be viewed as a proxy for projected increases in $\mathrm{CO}_{2}$ and temperature (George et al., 2007). Understanding which and how tropical tree species succeed in urban conditions offers potential insights into how deciduous, dry evergreen, and wet evergreen forest types may respond to projected climate changes and potentially validate model predications. Such insights can be gleaned through the informal selection process of tropical urban trees for tolerance to urban stresses, in particular urban heat, islands, and planting into confined, droughtprone urban soils.

\section{TROPICAL FOREST TYPES AND ADAPTATION}

Lowland wet evergreen. Equatorial wet evergreen forests are the tropical jungles of the Western, temperate world's imagination. These forests largely but not exclusively fall within $10^{\circ} \pm$ latitude of the equator in three global regions: the Amazon basin in western South America, the Congo in central Africa, and the Insular Southeast Asian part of the Indomalayan region from the Kangar-Pattani line near the isthmus of Kra on the Malay peninsula to eastern New Guinea (Kottek et al., 2006). A simple characterization of these forests is aseasonal annual precipitation of over $2000 \mathrm{~mm}$ with each month receiving at least $60 \mathrm{~mm}$ of rainfall (Kottek et al., 2006), resulting in no distinct dry season.

Because water is not limiting in equatorial wet evergreen forests, plants compete for the limiting resources of nitrogen and light (Graha et al., 2003). Light is particularly limiting for seedling recruitment. Whole-plant shade tolerance is a key physiological adaptation, because seedlings linger in the understory until a gap allows enough light for vigorous growth (Baltzer and Thomas, 2007). Because seedlings need not allocate resources to adapt to limited water, the wet evergreen half of cogeneric species pairs exhibited higher growth rates than cousins that grew in monsoonal habitats with distinct dry seasons
(Baltzer et al., 2007). An indication of adaptation to year-round wet habitats, upper canopy tree species in aseasonal wet forests maintained high photosynthesis rates at low levels of vapor deficits but exhibit steep stomatal closure and reduced photosynthesis as vapor deficits increase (Cunningham, 2006).

Also because water is not limiting, wet evergreen species typically have shallower root systems than monsoonal dry forest species (Schenk and Jackson, 2005). Shallower roots are more effective at scavenging scarce nitrogen from duff decomposition (Santiago et al., 2004). With less biomass needed for deep root production, wet evergreen species invest more biomass in leaves (Santiago et al., 2004) that are long-lived and more efficient nitrogen users (Wright et al., 2002).

Wet evergreen species appear to lack drought tolerance traits as a tradeoff for light and nitrogen-scavenging traits (BrenesArguedas et al., 2008). Not surprisingly, species from aseasonal climates are less droughttolerant at the physiological level than species found in monsoonal dry habitats (Baltzer et al., 2007). Wet evergreen species have less desiccation-tolerant leaves (Baltzer et al., 2008) and xylem hydraulic properties (Baltzer et al., 2009), particularly at the seedling recruitment stage (Kursar et al., 2009). Model projections suggest wet evergreen forest species apparently do not have the adaptive traits necessary to penetrate into drier forests through seedling recruitment (Comita and Engelbrecht, 2009; Kursar et al., 2009) and thus will likely retreat where climate shifts to more extended rain-free periods (Malhi et al., 2009).

Downscaled climate projections linked to ecological models suggest potential redistribution in tropical forest habitats (Trisurat et al., 2009). However, down-scaled climate projections for equatorial forests do not provide a consensus on shifts in precipitation, as rainfall patterns are dependent on local, difficult-to-model conditions and thus challenging to capture in global climate models functioning on a larger scale (Phillips, 2007). However, on a broad scale, models suggest that very subtle changes in moisture will likely cause wet evergreen forests to retreat at their edges where there is decreased rainfall (Enquist, 2002; Malhi et al., 2009) or increased evapotranspiration shifts the climate to a more negative water balance (Delire et al., 2008).

Tropical wet evergreen forest species are essentially specialists attuned to a relatively specific set of environmental conditions (Woodruff, 2010) and where drought is absent (Baltzer et al., 2007). Wet evergreen forests also function within a narrow temperature range (Woodruff, 2010); thus, physiological and morphological mechanisms to survive greater water and temperature ranges are not evident (Baltzer et al., 2007, 2008, 2009; Kursar et al., 2009). Model projections based on increased temperature suggest a high level of species turnover and habitat changes that will push species to different locations with newly suitable habitat (Hilbert et al., 2001; Miles et al., 2004; Trisurat et al.,
2010). In other words, many wet evergreen forest species will be subject to environmental conditions more suitable to a different forest type and either move or perish (Hilbert et al., 2001).

Empirical observations of changes in growth largely support model projections if not theoretical speculation. Cursory assumptions regarding the impact of elevated $\mathrm{CO}_{2}$ on forest types suggest greater water use efficiency resulting from $\mathrm{CO}_{2}$ fertilization (Korner, 2009). However, empirical growth measurements in a tropical forest over the past 30 years detected no evidence of positive $\mathrm{CO}_{2}$ effects but did report negative effects on growth related to elevated nighttime low temperatures of 1 to $2{ }^{\circ} \mathrm{C}$ (Clark et al., 2010). Similarly, empirical measurements in wet evergreen forests in Malaysia and Central America reported decelerating growth rates, also linked to elevated nighttime low temperatures, but also to decreasing number of rainfree days (Feeley et al., 2007). The relationship with decreasing rain-free days suggests lack of sunlight may be another climate change factor affecting wet evergreen forest distribution; paleoclimate reconstruction indicated extensive cloudiness limited growth in montane forests in Southeast Asia (Buckley et al., 2007).

Which wet evergreen species in Southeast Asia may shift to suitable new locations will vary with the velocity of projected temperature increases (Loarie et al., 2009) and inherent evolutionary capacity (Woodruff, 2010). Paleoclimate reconstruction suggests that extant species with limited range, particularly those from understory habitats, would appear vulnerable to habitat loss and likely less able to migrate to new ranges (Davidar et al., 2008); by contrast, widely distributed species with greater genetic flexibility are more likely to successfully migrate (Baltzer et al., 2008; Miles et al., 2006). Wet evergreen forest species used in tropical cities, particularly as street trees, are likely to reflect the characteristics of those species able to tolerate a wide range of conditions. Under future climate change, this suggests that increasing urban tree diversity to include wet evergreen forest species will be more successful when selecting seed of species with provenances at the edges of wide distributional ranges.

Montane wet evergreen. A subset of wet evergreen forest habitats includes montane forests. These forests exist in cooler, higher elevation climates than lowland wet evergreen forests in a broader latitudinal range up to the edge of the tropics. Higher elevation translates to cooler temperatures and thus lower vapor deficits and evapotranspiration, resulting in a more favorable water balance (Tanaka et al., 2003). In Southeast Asia, many montane forests are subject to monsoonal dry periods. Evapotranspiration peaks during the dry season and the presence of deep soils suggests that water stress is not a decisive factor in characterizing this forest type (Tanaka et al., 2008).

However, cloud forests with persistent canopy-level fog are a highly specialized subset 
( $8 \%$ to $15 \%)$ of tropical montane forests that would be very decisively affected by water stress (Bubb et al., 2004). Cloud forests are found in narrow altitudinal bands ranging from 1000 to $3500 \mathrm{~m}$ elevation with numerous endemic tree species particularly vulnerable to increasing temperatures and changes in water balance (Foster, 2001).

Montane forests in Southeast Asia are unique in being refugia of species formerly more widespread during glacial periods of lower temperatures and lower sea levels (Woodruff, 2010). Glacial periods allowed dispersal of Asian boreotropical species from genera such as Acer, Fraxinus, Salix, Picea, and Abies (Anderson and Muller, 1975) that subsequently retreated during warmer interglacial periods. In Southeast Asian montane forests, the Fagaceae have been the most successful in colonizing and speciating into a wider range and thus are the dominant montane forest type in many highland areas (Culmsee et al., 2010).

Tropical montane species existing at their temperature limits are in a precarious position under future projected temperature increases. Although the velocity of temperature change in montane regions is likely to be slow (Loarie et al., 2009), montane species are more likely to be very vulnerable to habitat loss (Enquist, 2002), because they have nowhere else to go (Foster, 2001). Even if rainfall is unaffected, higher temperatures in montane regions will result in higher evapotranspiration demand (Delire et al., 2008) and a more negative water balance may cause increased water stress and habitat loss (Tanaka et al., 2008). Likely as a result of their temperature limits, and limited adaptability to water stress, montane species are not typically found in urban tree populations in either monsoonal or wet equatorial cities.

Monsoonal dry forests. Monsoonal dry forests are found within the tropical latitudes where the dry season is long enough to cause routine water soil water deficits, despite episodic rainfall, but wet season duration is sufficient to support a forest canopy. Because of the extended dry season, monsoonal species appear to be more deeply rooted than any other forest type (Schenk and Jackson, 2005), although coarse-textured soil can sometimes create deciduous islands in otherwise evergreen forests (Bohlman, 2010). Dry forests are a significant ecosystem in the monsoonal tropics whose rich animal and plant biodiversity, particularly in their more illuminated understory, is under threat from a range of anthropogenic activities (Miles et al., 2006). The biodiversity of tropical dry forests yields many economically important timber and medicinal species (Johnson and Grivetti, 2008) as well as a source of genetic diversity for breeding programs (Purushothaman et al., 2000).

Where soil nutrient levels are low, evergreen species are typically favored, sometimes mixed with deciduous species (Choat et al., 2005; Ishida et al., 2006). Dry evergreen forest species must tolerate intense solar radiation, heat, and drought during the dry season and low light and high rainfall during the wet season (Graha et al., 2003). Dry evergreen forest species typically have small leaves relative to deciduous types to minimize heating and leaf-air vapor pressure gradient during the dry season (Pittman, 1996). These species are evergreen to conserve nitrogen and have a much greater investment in leaf mass per unit area and in increasing leaf longevity (Wright et al., 2002) to tolerate low leaf water potentials and survive desiccation (Brodribb et al., 2003; Pittman, 1996) during the extended dry season. Dry evergreen forest species typically have lower stomatal conductance $\left(g_{\mathrm{S}}\right)$ and photosynthetic rates than deciduous species (Choat et al., 2005; Ishida et al., 2006) and a lower hydraulic conductance that limits $g_{\mathrm{S}}$ and lowers internal water potentials (Brodribb et al., 2003; Ishida et al., 2006).

Deciduous species in monsoonal dry forests tend to occupy more nutrient-rich soils where fire can determine a particular forest subtype (Miles et al., 2006). Dry deciduous species typically have high transpiration rates and hydraulic conductivity to maximize productivity during the wet season foliation and then enter senescence and defoliate at some point during the dry season (Choat et al., 2005; Ishida et al., 2006). Deciduous dry forest tree species, in fertile soil where the cost of nutrient loss is not limiting, exhibit a remarkable array of adaptations in response to extreme seasonal wetness and drought. Drought deciduous species vary in strategies for leaf longevity and length of dormancy in response to drought (Elliot et al., 2006), and in hydraulic properties. Some species may allow xylem cavitation and defoliate in response to modest water stress at relatively less negative internal water potentials and initiate refoliation with new xylem as rainfall increases soil water content with the onset of the wet monsoon season (Brodribb et al., 2002). Others species extend sensitivity to mild water stress to the point of avoiding cavitation entirely to maintain functional xylem while defoliated. This sensitivity minimizes soil water depletion and maximizes high soil water contents and allows refoliation and sunlight capture before the onset of the wet season subsequent to increased competition for sunlight (Brodribb et al., 2003; Elliot et al., 2006). Some drought deciduous species have high trunk water storage capacitance as a result of unique wood anatomy that allows these species to tolerate low soil water potentials (Borchert and Pockman, 2005).

However, hydraulic signaling appears to be an incomplete explanation for droughtinduced dormancy. Changes in hydraulic properties do not correlate to gas exchange reduction before senescence in many tropical deciduous species (Brodribb et al., 2002, 2003). Leaf size and heating may provide a possible alternative explanation for droughtinduced dormancy in these species. A number of drought deciduous species have relatively large leaves rarely found in full sun habitats such as Tectona grandis L. f. (teak) and a number of dipterocarp species (Sales-Come and Holscher, 2010). Large leaves would necessitate high transpiration rates to facilitate evaporative cooling and maintain photosynthetically optimum leaf temperatures, a characteristic consistent with high $g_{\mathrm{S}}$ and wide xylem vessels capable of high hydraulic conductance found in drought deciduous species (Choat et al., 2005; Ishida et al., 2006).

High transpiration rates, particularly those species with large leaves, suggest a possible defoliation signal in drought deciduous species. These species appear to have stomata sensitive to leaf-air vapor pressure gradient (LAVPD) (Ishida et al., 2006). Initial dry season mild water stress appears to trigger a rapid and large drop in $g_{\mathrm{S}}$ in response to a small change in soil water potential with minimal cavitation and negligible loss of xylem function (Brodribb et al., 2003). A large decrease in $g_{\mathrm{S}}$ somewhat decoupled from water potential can be explained by a feed-forward process mediated by LAVPD and enhanced by large leaf size, in which a small reduction in conductance from soil drying reduces transpirational cooling. Reduced transpirational cooling would increase leaf temperature and LAVPD, which in turn would push conductance even lower and LAVPD higher in a feed-forward loop. Buildup of leaf-level abscisic acid (ABA) has been linked to stomatal closure in trees not only during soil drying (Bauerle et al., 2003), but also in very dry air conditions that cause high LAVPD (Bauerle et al., 2004). Thus, a large-leafed species could reach rapid stomatal closure from small changes in soil drying and decreased internal water potential resulting from leaf heating that in turns triggers ABA buildup to the point of leaf senescence.

Few have investigated potential impacts of climate change on monsoonal dry forests. Empirically, paleoclimate reconstructions in tropical Africa suggest drying conditions are limiting monsoonal forest growth (Schongart et al., 2006). Modeling climate change impacts on tropical forests offers insights into how tropical forests types, and tree species, may respond to elevated temperatures and rainfall variability. In the Neotropics, one modeling effort suggests that monsoonal deciduous forests may be sensitive to a hotter climate (Enquist, 2002) because of habitat turnover. However, Trisurat et al. (2009) modeled the impact of the IPCC A2 climate change scenario in northern Thailand and reported higher habitat turnover in areas with dry evergreen species that were displaced to higher elevations and replaced by deciduous species. They suggested the deciduous species have greater tolerance to drought duration and higher temperatures than evergreen species. Avoiding drought through leaf drop and moderating higher temperatures through high transpiration rates would suggest that deciduous species could be more resilient to climate change than evergreen species, a competitive advantage in a hotter, drier climate. Evaluating species types in tropical cities, which can serve as proxy for climate change (George et al., 2007), can yield empirical insights into potential changes in species' native 
distribution under climate change and, reciprocally, insights into urban species selection for tropical cities.

\section{TROPICAL URBAN FOREST SPECIES}

Cities are a reasonable proxy for climate change (George et al., 2007). Anthropogenic $\mathrm{CO}_{2}$ emissions creates a dome of elevated urban concentrations (George et al., 2007), subjecting urban trees to $\mathrm{CO}_{2}$ fertilization. Also, urban heat islands are characteristic of all cities arising from increased sensible and re-radiated heat from impervious surfaces (Rizwan et al., 2008). In tropical/subtropical regions, cities with pronounced monsoonal dry seasons may experience particularly intense heat islands (Roth, 2007). Although vegetation can mitigate heat island impact (Roth, 2007), urban vegetation in tropical cities will be the first to be affected by elevated temperatures through increased heat loading from asphalt (Kjelgren and Montague, 1998) and other non-transpirating surfaces (Montague and Kjelgren, 2004). Freestanding, isolated street tree crowns in particular will be subject to high heat loading (Kjelgren and Clark, 1993) analogous to higher temperatures associated with climate change. The degree of heating depends on sensible heat dissipation as a function of leaf size (Leuzinger et al., 2010) and $g_{\mathrm{S}}$ that determines the degree of coupling of the leaf with the atmosphere (Jarvis and McNaughton, 1986). Finally, tree water stress in urban areas is common (Close et al., 1996) as a result of confined root zones, either resulting from limited volume or depth (Bondarenko, 2009), and is analogous to drought imposed through changes in rainfall patterns.

Studies of street tree populations in Bangkok, Thailand (Thaiutsa et al., 2008) and Bangalore, India (Nagendra and Gopal, 2010) suggest similar responses to the findings of Trisurat et al. (2010) in northern Thailand dry forests. Both cities have pronounced monsoonal climates with a 4- to 6-month dry season and a majority of deciduous species in their street tree populations (Table 1). In both cities, evergreen species were only one-third of the top 15 most commonly used street tree species, and these species were largely from drier, harsher habitats, rather than from wet equatorial forests. Minority evergreen species in both cities from monsoonal dry habitats included several Eucalpytus species and Markhamia lutea (Benth.) K. Schum. in Bangalore and in Bangkok, Tamarindus indica L., Swietenia macrophylla King and Polyalthia longifolia Sonner. Two other Bangkok evergreen street trees, Mimusops elengi L. and Calophyllum inophyllum L., are from a wide range of harsher conditions, including saltaffected and sandy seashore habitats.

Use of deciduous species in tropical cities in Asia appears to be the result of an informal selection process. Thaiutsa et al. (2008) also surveyed large-specimen trees in Bangkok that were much older than the street tree population (Table 2). These specimen trees were dominated by evergreen species from dry evergreen forests, particularly in the genus Ficus, rather than deciduous species. Only four specimen species were common to the top 15 Bangkok street trees and in the top 15 specimen tree lists with two deciduous species that were in common. This lack of crossover suggests that evergreen species even from dry habitats did not perform as well as deciduous species in urban areas, resulting in further use of deciduous species as street trees, consistent with the findings of Trisurat et al. (2009). The ostensible heat tolerance limitation of evergreen species is consistent with Woodruff's (2010) observation that the current distributions of evergreen tropical forests, certainly from aseasonal but possibly also seasonal habitats (Trisurat et al., 2009), reflect their temperature limits and may be vulnerable to increased temperatures from climate change.

Conversely, tropical drought deciduous species also appear adapted to wet equatorial habitats, but wet evergreen species do not appear to migrate into drier habits. Of 65 common urban trees for Singapore (Tee and
Wee, 2001), 37\% were deciduous species from monsoonal areas. Seventeen species on the Singapore tree list were also among the most common street trees in Bangkok and Bangalore and the specimen trees of Bangkok (Table 3). Of these common species, $59 \%$ were deciduous, but again the evergreen species were largely from dry forests, not equatorial wet evergreen forests. This suggests that tree species from monsoonal habitats can be used in cities with aseasonal, equatorial wet climates, where deciduous species may stay evergreen or briefly lose their leaves. The reciprocal does not appear to hold, because species from aseasonal wet evergreen forests appear intolerant of dry conditions typical of tropical cities in monsoonal climates. Seasonal drought as the limiting factor for wet evergreen species is consistent with the observation that these species simply lack physiological drought adaptation (Baltzer et al., 2008, 2009; Comita and Engelbrecht, 2009) to survive drier conditions and that they may be at their temperature limits (Woodruff, 2010).

Table 1. Street tree species common to Bangkok, Thailand (from Thaiutsa et al., 2008) and Bangalore, India (from Nagendra and Gopal, 2010), in alphabetical order, where abundance rank is the number of individual trees for a species relative to the other street tree species in each city.

\begin{tabular}{llccrc}
\hline & & Leaf & & \multicolumn{2}{c}{ Abudance rank } \\
\cline { 3 - 6 } Species & Family & habit & Native distribution & Bangkok & Bangalore \\
\hline Delonix regia & Fabaceae & D & Africa & 10 & 8 \\
Lagerstroemia speciosa & Lythraceae & D & Southeast Asia & 2 & 15 \\
Millingtonia hortensis & Bignoniaceae & D & Southeast Asia & 13 & 10 \\
Peltophorum pterocarpum & Fabaceae & D & Southeast Asia & 9 & 2 \\
Polyalthia longifolia & Annonaceae & E & Southeast Asia & 7 & 6 \\
Swietenia macrophylla & Meliaceae & E & South America & 5 & 7 \\
\hline
\end{tabular}

Table 2. Specimen tree species in Bangkok, Thailand (from Thaiutsa et al., 2008) also found as common street trees in Bangkok and Bangalore, India, in alphabetical order.

\begin{tabular}{llcccc}
\hline & & & \multicolumn{2}{c}{ Also street tree in: } \\
\cline { 4 - 6 } Specimen species & Family & Leaf habit & Native distribution & Bangkok & Bangalore \\
\hline Albizia saman & Fabaceae & D & South America & - & X \\
Mimusops elengi & Sapotaceae & E & Southeast Asia & X & - \\
Pterocarpus indicus & Fabaceae & D & Southeast Asia & X & - \\
Tamarindus indica & Fabaceae & E & Africa & X & - \\
\hline
\end{tabular}

Table 3. Most common urban trees of Singapore also found as street trees in Bangkok, Thailand, Bangalore, India, or as large specimens in Bangkok in alphabetical order.

\begin{tabular}{|c|c|c|c|c|c|c|}
\hline \multirow{2}{*}{$\begin{array}{l}\text { Recommended Singapore } \\
\text { urban tree species }\end{array}$} & \multirow[b]{2}{*}{ Family } & \multirow{2}{*}{$\begin{array}{l}\text { Leaf } \\
\text { habit }\end{array}$} & \multirow[b]{2}{*}{ Native distribution } & \multicolumn{2}{|c|}{ Street tree in } & \multirow{2}{*}{$\begin{array}{c}\text { Bangkok } \\
\text { large } \\
\text { tree }\end{array}$} \\
\hline & & & & Bangkok & $\overline{\text { Bangalore }}$ & \\
\hline Albizzia saman & Fabaceae & $\mathrm{D}$ & Tropical America & - & $\mathrm{X}$ & $\mathrm{X}$ \\
\hline Calophyllum inophyllum & Guttiferae & $\mathrm{E}$ & Asia & $\mathrm{X}$ & - & - \\
\hline Cassia fistula & Fabaceae & $\mathrm{D}$ & Southeast Asia & $X$ & - & - \\
\hline Couruopita guianensis & Lecythidaceae & $\mathrm{D}$ & Tropical America & - & - & $\mathrm{X}$ \\
\hline Delonix regia & Fabaceae & $\mathrm{D}$ & Africa & $X$ & $\mathrm{X}$ & - \\
\hline Eucalyptus species & Myrtaceae & $\mathrm{E}$ & Australia & - & $\mathrm{X}$ & - \\
\hline Hopea odorata & Dipterocarpaceae & $\mathrm{E}$ & Asia & - & - & $X$ \\
\hline Jacaranda mimosifolia & Fabaceae & $\mathrm{D}$ & Tropical America & - & $\mathrm{X}$ & - \\
\hline Lagerstroemia species & Lythraceae & $\mathrm{D}$ & Asia & $\mathrm{X}$ & $X$ & - \\
\hline Mimusops elengi & Sapotaceae & $\mathrm{E}$ & Southeast Asia & $\mathrm{X}$ & - & $\mathrm{X}$ \\
\hline $\begin{array}{l}\text { Peltophorum } \\
\text { pterocarpum }\end{array}$ & Fabaceae & $\mathrm{D}$ & Southeast Asia & $\mathrm{X}$ & $X$ & - \\
\hline Polyalthia longifolia & Annonaceae & $\mathrm{E}$ & South Asia & $\mathrm{X}$ & $\mathrm{X}$ & - \\
\hline Pongamia pinnata & Fabaceae & $\mathrm{D}$ & South Asia & - & $\mathrm{X}$ & - \\
\hline Pterocarpus indicus & Fabaceae & $\mathrm{D}$ & Southeast Asia & $\mathrm{X}$ & - & $\mathrm{X}$ \\
\hline Swietenia macrophylla & Meliaceae & $\mathrm{E}$ & Tropical America & $\mathrm{X}$ & $X$ & - \\
\hline Tabebuia rosea & Bignoniaceae & $\mathrm{D}$ & Tropical America & $\mathrm{X}$ & - & - \\
\hline Tamarindus indica & Fabaceae & $\mathrm{E}$ & Africa & X & - & $\mathrm{X}$ \\
\hline
\end{tabular}


That tropical cities appear to be a reasonably proxy for potential climate change impacts is evidenced in the relative abundance of drought deciduous tree species that appear to have greater physiological tolerances for higher temperatures and potential droughthigh transpiration rates and greater transpirational cooling and deciduousness to avoid drought - than dry evergreen species and more emphatically wet evergreen species. The ostensible abundance of monsoonal dry forest species compared with wet evergreen species in cities as climate change proxies is certainly consistent with empirical observations of greater range distribution and drought tolerance than wet evergreen forest species (Baltzer et al., 2008). More specifically within dry forest types, the urban abundance of drought deciduous relative to dry evergreen forest species is also consistent with model results suggesting drought deciduous species will gain in hotter lowland area at the expense of dry evergreen species. These parallels would indicate that tree species' success in urban climates yields insights into potential impacts on forest types in their natural habitats.

Future selection of tree species for Southeast Asian tropical cities can be guided by dendroclimate studies, ecophysiological investigation, and ecological modeling. Given historical potential for monsoonal failure and severe drought (Cook et al., 2010), potential shifting of rainfall patterns resulting from climate change, and established drought tolerance limits, monsoonal forests may prove to be a logical prospecting source for tree species to diversify the tropical urban forest. Indeed, the National Parks Board managing Singapore's urban green infrastructure over the past decade has included drought tolerance as measured by natural habitat in its urban tree selection criteria. Ecological modeling suggests a possible means for selecting tropical urban tree species in a hotter climate that are tolerant of even more intense urban heat islands. Modeling studies, e.g., Trisurat et al. (2009), would suggest that species projected to have less habitat area turnover or expanded total area, either deciduous or evergreen, are likely to tolerate urban conditions more effectively. Certainly a mixture of evergreen and deciduous species will be desirable in tropical cities, particularly those with dry seasons, because evergreen species provide needed dry season shade and heat mitigation, whereas deciduous species provide greater ornamental benefits from flowering.

\section{Literature Cited}

Anderson, J.A. and J. Muller. 1975. Palynological study of a Holocene peat and a Miocene coal deposit from new Borneo: A review. Paleobot. and Palynol. 19:291-317, 319, 321, 323-351.

Baltzer, J.L., S.J. Davies, S. Bunyavejchewin, and N.S.M. Noor. 2008. The role of desiccation tolerance in determining tree species distributions along the Malay-Thai Peninsula. Funct. Ecol. 22:221-231.

Baltzer, J.L., S.J. Davies, A.R. Kassim, and J.V. LaFrankie. 2007. Geographical distributions in tropical trees: Can geographical range predict performance and habitat association in cooccurring tree species? J. Biogeogr. 34:916926.

Baltzer, J.L., D.M. Gregoire, S. Bunyavejchewin, N.S.M. Noor, and S.J. Davies. 2009. Coordination of foliar and wood anatomical traits contributes to tropical tree distributions and productivity along the Malay-Thai Peninsula. Amer. J. Bot. 96:2214-2223.

Baltzer, J.L. and S.C. Thomas. 2007. Determinants of whole-plant light requirements in Bornean rain forest tree saplings. J. Ecol. 95:1208-1221.

Bauerle, W.L., T.H. Whitlow, T.L. Setter, T.L. Bauerle, and F.M. Vermeylen. 2003. Ecophysiology of Acer rubrum seedlings from contrasting hydrologic habitats: Growth, gas exchange, tissue water relations, abscisic acid and carbon isotope discrimination. J. Amer. Soc. Hort. Sci. 129:182-187

Bauerle, W.L., T.H. Whitlow, T.L. Setter, and F.M Vermeylen. 2004. Abscisic acid synthesis in Acer rubrum L. leaves-A vapour-pressuredeficit-mediated response. J. Amer. Soc. Hort. Sci. 129:182-187.

Bohlman, S. 2010. Landscape patterns and environmental controls of deciduousness in forests of central Panama. Glob. Ecol. Biogeogr. 19: 376-385.

Bondarenko, V.V. 2009. Soil water regime and evapotranspiration of sites with trees and lawn in Moscow. PhD Diss., University of Wageningen, Wageningen, The Netherlands

Borchert, R. and W.T. Pockman. 2005. Water storage capacitance and xylem tension in isolated branches of temperate and tropical trees. Tree Physiol. 25:457-466.

Brenes-Arguedas, T., M. Rios, G. Rivas-Torres, C. Blundo, P.D. Coley, and T.A. Kursar. 2008. The effect of soil on the growth performance of tropical species with contrasting distributions. Oikos 117:1453-1460.

Brodribb, T.J. and N.M. Holbrook. 2005. Leaf physiology does not predict leaf habit; examples from tropical dry forest. Trees Struct. Funct. 19:290-295

Brodribb, T.J., N.M. Holbrook, E.J. Edwards, and M.V. Guteirrez. 2003. Relation between stomatal closure, leaf turgor and xylem vulnerability in eight tropical dry forest trees. Plant Cell Environ. 26:443-450.

Brodribb, T.J., N.M. Holbrook, and M.V. Guteirrez. 2002. Hydraulic photosynthetic coordination in seasonally dry tropical forest trees. Plant Cell Environ. 25:1435-1444

Bubb, P., I. May, L. Miles, and J. Sayer. 2004. Cloud forest agenda. United Nations Environment Programme World Conservation Monitoring Centre.

Buckley, B.M., K. Duangsathaporn, K. Palakit, S. Butler, V. Syhapanya, and N. Xaybouangeun. 2007. Analyses of growth rings of Pinus merkusii from Lao. PDR Forest Ecol Man. 253: 120-127.

Choat, B., M.C. Ball, J.G. Luly, and J.A. Holtum. 2005. Hydraulic architecture of deciduous and evergreen dry rainforest tree species in northeastern Australia. Trees (Berl.) 19:305-311.

Clark, D.B., D.A. Clark, and S.F. Oberbauer. 2010. Annual wood production in a tropical rain forest in NE Costa Rica linked to climatic variation but not to increasing $\mathrm{CO}_{2}$. Glob. Change Biol. 16:747-759.

Close, R.E., J.J. Kielbaso, P.V. Nguyen, and R.E. Schutzki. 1996. Urban vs. natural sugar maple growth: II. Water relations. J. Arboricult. 22: 187-192.

Comita, L.S. and B.M.J. Engelbrecht. 2009. Seasonal and spatial variation in water availability drive habitat associations in a tropical forest. Ecology 90:2755-2765.

Cook, E.R., K.J. Anchukaitis, B.M. Buckley, R.D. D'Arrigo, G.C. Jacoby, and W.E. Wright. 2010. Asian monsoon failure and megadrought during the last millennium. Science 328:486489.

Culmsee, H., C. Leuschner, G. Moser, and R. Pitopang. 2010. Forest aboveground biomass along an elevational transect in Sulawesi, Indonesia, and the role of Fagaceae in tropical montane rain forests. J. Biogeogr. 37:960-974.

Cunningham, S.C. 2006. Effects of vapour pressure deficit on growth of temperate and tropical evergreen rainforest trees of Australia. Acta Oecol. 30:399-406.

Davidar, P., B. Rajagopal, M. Arjunan, and J.P. Puyravaud. 2008. The relationship between local abundance and distribution of rain forest trees across environmental gradients in India. Biotropica 40:700-706.

Delire, C., A. Ngomanda, and D. Jolly. 2008 Possible impacts of 21 st century climate on vegetation in Central and West Africa. Global Planet. Change 64:3-15.

Deloya, M.C. 1993. Urban forestry activities in Mexico. Unasylva 173:28-32.

Elliot, S., P.J. Baker, and R. Borchert. 2006. Leaf flushing during the dry season; the paradox of Asian monsoon forests. Glob. Ecol. Biogeogr. 15:248-257.

Enquist, C.A.F. 2002. Predicted regional impacts of climate change on the geographical distribution and diversity of tropical forests in Costa Rica. J. Biogeogr. 29:519-534.

Feeley, K.J., S.J. Wright, M.N.N. Supardi, A.R. Kassim, and S.J. Davies. 2007. Decelerating growth in tropical forest trees. Ecol. Lett. 10: $461-469$.

Foster, P. 2001. The potential negative impacts of global climate change on tropical montane cloud forests. Earth Sci. Rev. 55:73-106.

George, K., L.H. Ziska, J.A. Bunce, and B. Quebedeaux. 2007. Elevated atmospheric $\mathrm{CO}_{2}$ concentration and temperature across an urbanrural transect. Atmos. Environ. 41:7654-7665.

Graha, E.A., S.S. Mulkey, K. Kitajima, N.G. Phillips, and S.J. Wright. 2003. Cloud cover limits net $\mathrm{CO}_{2}$ uptake and growth of a rainforest tree during tropical rainy seasons. Proc. Natl. Acad. Sci. USA 100:572-576.

Hilbert, D.W., B. Ostendorf, and M.S. Hopkins. 2001. Sensitivity of tropical forests to climate change in the humid tropics of north Queensland. Austral Ecol. 26:590-603.

Ishida, A., S. Diloksumpun, P. Ladpala, D. Staporn, S. Panuthai, M. Gamo, K. Yazaki, M. Ishizuka, and L. Puangchit. 2006. Contrasting seasonal leaf habits of canopy trees between tropical dry-deciduous and evergreen forests. Tree Physiol. 26:643-656.

Jarvis, P. and K. McNaughton. 1986. Stomatal control of transpiration: Scaling up from leaf to region. Adv. Ecol. Res 15:1-49.

Jim, C.Y. 2001. Managing urban trees and their soil envelopes in a contiguously developed city environment. Environ. Manage. 28:819-832.

Jim, C.Y. and H.T. Liu. 2001. Patterns and dynamics of urban forests in relation to land use and development history in Guangzhou City, China. Geogr. J. 167:358-375.

Johnson, N. and L.E. Grivetti. 2008. Environmental change in northern Thailand: Impact on wild edible plant availability. Ecol. Food Nutr. 41: 373-399.

Kjelgren, R. and J. Clark. 1993. Growth and water relations of Liquidambar styraciflua $\mathrm{L}$ in an urban park and plaza. Trees (Berl.) 7:195-201. 
Kjelgren, R. and T. Montague. 1998. Urban tree transpiration over turf and asphalt surfaces. Atmos. Environ. 32:35-41.

Korner, C. 2009. Response of humid tropical trees to rising $\mathrm{CO}_{2}$. Annu. Rev. Ecol. Evol. Syst. 40: 61-79.

Kottek, M., J. Grieser, C. Beck, B. Rudolf, and F. Rubel. 2006. World map of the Köppen-Geiger ddclimate classification updated. Meteorol. Z. 15:259-263.

Kursar, T.A., B.M.J. Engelbrecht, A. Burke, M.T. Tyree, B. El Omari, and J.P. Giraldo. 2009. Tolerance to low leaf water status of tropical tree seedlings is related to drought performance and distribution. Funct. Ecol. 23:93-102.

Leuzinger, S., R. Vogt, C. Korner, and C. 2010. Tree surface temperature in an urban environment. Agr. For. Meteorol. 150:56-62.

Loarie, S.R., P.B. Duffy, H. Hamilton, G.P. Asner, C.B. Field, and D.D. Ackerly. 2009. The velocity of climate change. Nature 462:1052-1111.

Malhi, Y.L., C. Aragao, D. Galbraith, C. Huntingford, R. Fisher, P. Zelazowski, S. Sitch, C. McSweeney, and P. Meir. 2009. Exploring the likelihood and mechanism of a climate-change-induced dieback of the Amazon rainforest. Proc. Natl. Acad. Sci. USA 106:20610-20615.

Miles, L., A. Grainger, and O. Phillips. 2004. The impact of global climate change on tropical forest biodiversity in Amazonia. Glob. Ecol. Biogeogr. 13:553-565.

Miles, L., A.C. Newton, R.S. DeFries, C. Ravilious, I. May, S. Blyth, V. Kapos, and J. Gordon. 2006. A global overview of the conservation status of tropical dry forests. J. Biogeogr. 33:491505.

Montague, T. and R. Kjelgren. 2004. Energy balance of six common landscape surfaces and the influence of surface properties on gas exchange of four containerized tree species. Sci. Hort. 100:229-249.

Nagendra, H. and D. Gopal. 2010. Street trees in Bangalore: Density, diversity, composition and distribution. Urban For. Urban Green. 9:129137.
Nilsson, K. 2005. Urban forestry as a vehicle for healthy and sustainable development. Chinese For. Sci. Tech. 4:1-14.

Phillips, O.L. 2007. Drought, dispersal, and distribution in the inner tropics. J. Biogeogr. 34: 1846-1847.

Pittman, J. 1996. Ecophysiology of tropical dry evergreen forests, Thailand: Measured and modelled stomatal conductance of Hopeaferrea, a dominant canopy emergent. J. Appl. Ecol. 33:1366-1378.

Purushothaman, S., S. Viswanath, and C. Kunhikannan. 2000. Economic valuation of extractive conservation in a tropical deciduous forest in Madhya Pradesh, India. Trop. Ecol. 41:61-72.

Rizwan, A.M., Y.C.L. Dennis, and C.H. Liu. 2008. A review on the generation, determination and mitigation of urban heat island. J. Environ. Sci. (China) 20:120-128.

Roth, M. 2007. Review of urban climate research in (sub) tropical regions. Intl. J. Climatol. 27:18591873.

Sales-Come, R. and D. Holscher. 2010. Variability and grouping of leaf traits in multi-species reforestation (Leyte, Philippines). For. Ecol. Mgt. 260:846-855.

Santiago, L.S., K. Kitajima, S.J. Wright, and S.S. Mulkey. 2004. Coordinated changes in photosynthesis, water relations and leaf nutritional traits of canopy trees along a precipitation gradient in lowland tropical forest. Oecologia 139:495-502.

Schenk, H.J. and R.B. Jackson. 2005. Mapping the global distribution of deep roots in relation to climate and soil characteristics. Geoderma 126: 129-140.

Schongart, J., B. Orthmann, K.J. Hennenberg, S. Porembski, and M. Worbes. 2006. Climategrowth relationships of tropical tree species in West Africa and their potential for climate reconstruction. Glob. Change Biol. 12:1139-1150.

Tanaka, K., H. Takizawa, N. Tanaka, I. Kosaka, N. Yoshifuji, C. Tantasirin, S. Piman, M. Suzuki, and N. Tangtha. 2003. Transpiration peak over a hill evergreen forest in northern Thailand in the late dry season: Assessing the seasonal changes in evapotranspiration using a multilayer model. J. Geophys Res. 108:4-1-4-15.

Tanaka, N., T. Kume, N. Yoshifuji, K. Tanaka, H. Takizawa, K. Shiraki, C. Tantasirin, N. Tangtham, and M. Suzuki. 2008. A review of evapotranspiration estimates from tropical forests in Thailand and adjacent regions. Agr. For. Meteorol. 148: 807-819.

Tee, W.S. and L.M. Wee. 2001. Trees of our garden city: A guide to the common trees of Singapore. National Parks Board, Singapore.

Thaiutsa, B., L. Puangchit, R. Kjelgren, and W. Arunpraparut. 2008. Urban green space, street tree and heritage large tree assessment in Bangkok, Thailand. Urban For. Urban Green. 7:219-229.

Trisurat, Y., R. Alkemade, and E. Arets. 2009. Projecting forest tree distributions and adaptation to climate change in northern Thailand. J. Ecol. Nat. Environ. 1:55-63.

Trisurat, Y., S. Suraphabmiatree, and S. Saengnil. 2010. Plant species vulnerability to climate change during 2002-2100. National Research Council of Thailand, Bangkok, Thailand.

Tzoulas, K., K. Korpela, S. Venn, V. Yli-Pelkonen, A. Kazmierczak, J. Niemela, and P. James. 2007. Promoting ecosystem and human health in urban areas using green infrastructure: A literature review. Landsc. Urban Plan. 81:167-178.

United Nations Dept. Economic and Social Affairs. 2003. Long range population projections. New York. 30 June 2003. (Proc: U.N. Tech. Working Group on Long-Range Pop. Project).

Woodruff, D.S. 2010. Biogeography and conservation in Southeast Asia: How 2.7 million years of repeated environmental fluctuations affect today's patterns and the future of the remaining refugial-phase biodiversity. Biodiv. Cons. 19: 919-941.

Wright, I.J., M. Westoby, and P.B. Reich. 2002. Convergence towards higher leaf mass per area in dryand nutrient-poor habitats has different consequences for leaf life span. J. Ecol. 90: 534-543. 